\title{
PUBLIC VIRTUES AND PRIVATE PLEASURES: HOW TV CULTURE EMERGED IN SOCIALIST YUGOSLAVIA
}

\author{
UDC 316.774:654.197(497.1)
}

\author{
Ildiko Erdei \\ University of Belgrade, Faculty of Philosophy, \\ Department of Ethnology and Anthropology, Serbia
}

\begin{abstract}
Television represented the transformative technology in the 20th century, and it has also served as a major social and cultural force for modernization after World War II, on both sides of the Iron Curtain. In socialist countries television was closely connected with future-oriented ideology, and aimed to provide the democratization of knowledge, promotion of socialist values and development of socialist citizenry. The beginning of TV broadcast in socialist Yugoslavia in 1958 gave way to the gradual development of TV culture during the sixties and seventies, the overall impact of which on the subjectivities and everyday lives of the viewers was undeniable. The aim of this paper is to briefly outline the context in which television culture in socialist Yugoslavia emerged and achieved momentum, pinpointing two periods: the penetration of TV into small places and villages during the sixties and the socio-cultural influence and ramifications of the broadcast of "Peyton Place" in the early seventies.
\end{abstract}

Key words: TV culture, Belgrade Television, viewing practices, "Peyton Place".

\section{INTRODUCTION}

Recent research on television in socialism, whether coming from the media and political studies or from social sciences and humanities, has affirmed the need to shed more light on the investigation of media cultures and their relation to broader sociocultural processes such as nation building and modernization (see: Mickiewitcz 1988, Dragičević-Šešić 2007, Bren 2011, Mihelj 2013, 2013a, 2014, 2017, Malešević 2012, Havens, Imre and Lustyik 2013, Gumbert 2014, Imre 2014, 2016, Erdei 2015, 2017, Simeunović-Bajić 2016, 2018, Bardan 2017, Mihelj and Huxtable 2018). It has also revealed the way in which popular television (see: Havens, Imre and Lustyik 2013) in Eastern and Central Europe was employed by socialist regimes to regain their legitimacy after a series of political turmoil

Received June 28, 2020 / Accepted September 19, 2020

Corresponding author: Ildiko Erdei

University of Belgrade, Faculty of Philosophy, Čika Ljubina 18-20, 11000 Belgrade, Serbia

E-mail: ildierdei@gmail.com 
which culminated in mass protests in Czechoslovakia (also in Yugoslavia) in 1968 (see: Bren 2011, Imre 2016). Furthermore, it indicates how television, and particularly "light" TV genres, such as humoristic series, quizzes, cabarets etc. had participated in the creation of socialist modernity. Due to their popularity, these TV shows created a mass of followers, and thus provided long-term influence on them, concerning both a desirable socialist attitude and visions and ideas of the Western/American way of life. ${ }^{1}$ Early histories of television on both sides of the Iron Curtain have many similar features - public broadcasting had a remarkable role, the informative and educational functions of national broadcasting were salient (see Mihelj 2013, 253; Mihelj 2013a, 20-21). In the course of later developments - technological, economic, political, social - and rapid commercialization of television in Western countries from the late 1970s, television in socialist countries retained the idea of public broadcasting in its purer form for much longer. "Eastern European socialist tv reproduced in more pure form and preserved well into the 1980s the educational principles and realistic aesthetic that Western European public broadcasters gradually abandoned under pressure from competition with commercial broadcasters" (Imre 2016, 28). In essence, social life of television as an institution, and cultural practices of TV watching were taking place at the intersection between the public and private sphere, in a space molded by attempts of different actors. As Imre $(2016,3)$ puts it: "In the most obvious sense, it was an institution that lived in the intersection of the public and domestic spheres, between top-down attempts at influencing viewers and bottom-up demands for entertainment".

Socialist Yugoslavia was seen as a "rogue socialist country" (Imre 2016, 33) in many respects, including the history of its national television. Rather early, the refusal of Tito's regime to blindly comply to political directives of the Soviet Union resulted in the creation of an alternative branch of Yugoslav socialism, whose defining feature came to be the project of self-government, based on "three D-s": "de-bureaucratization through workers' councils, decentralization of government, politics and culture, and democratization in all areas of life" (Čalić 2013, 238). This alternative model of development was accompanied by increasing openness to the West, where financial aid but also social and cultural influences were coming from. That included TV programming, which makes the history of Yugoslav television interesting for the investigation of complex relations that existed between the "East" and "West", including the porosity of the "Iron Curtain". Still, although there are significant contributions to the research of television in socialist Yugoslavia (referred to in the first paragraph), the history of TV remains fragmentary. From an anthropological perspective, what is missing in the research of TV in Yugoslav socialism is a position which Lila AbuLughod called "careful ethnography - ethnography that illuminates what Brian Larkin calls 'the social space' of television" (Abu-Lughod 1997, 111). Embedding television - as a technology, institution, media and artifact - into a complex social fabric of everyday life (of the nation and of the individual), and creating accounts which will relate to that complexity is still a task waiting to be done. In that respect, this paper aims to be a humble contribution to this still emerging field of multidisciplinary research of TV in Yugoslav (post)socialism, from an anthropological perspective.

\footnotetext{
1 During the sixties American TV series dominated the TV schedule. The first TV series broadcast in Yugoslavia was "The Long, Hot Summer", whose main protagonists gained enormous popularity and were welcomed with great enthusiasm during their visit to the country. The same happened with the TV series "Peyton Place", which became a source of cultural influences concerning everyday life - girls modelled their hair after the actresses', boys mimicked the postures and gestures of the main actors. Together, they found pleasure in watching the everyday life of the local close knit community on the screen, which enabled them to reflect on their own relations with other people in real life.
} 
In order to explain this perspective in more detail, I will take another route (which is not uncommon in an anthropological approach; see Miller 1996, 30-34 for a definition of consumption in anthropology) and explain what is not the aim of this paper: it is not to discuss the relation between the center and periphery, although it touches on the dissemination of TV from "urban centers" to the "countryside"; it is not to trace the role of TV in postwar urbanization, although it indicates how TV - taken as a technology, institution, medium and domestic object - has transformed the everyday lives of people, its new audiences; it is not to "target" any group that is subject of modernization, though it presents experiences of people outside the mainstream forces of modernization who were gradually, year by year and decade by decade, involved in and encompassed by the project of socialist modernity. The aim of the paper is to briefly outline the context of the emerging of TV culture in socialist Yugoslavia. Instead to single out one particular issue, process and/or group of people, in this paper I concentrate on contextualization as a main anthropological tool to arrive at and bring about the complexities and interconnections of social situations and cultural relations. In this concrete example, a contextualizationcentered approach touches on all of the above-mentioned issues, processes and/or groups of people, but neither of these is pursued per se. They are seen as embedded in a context and mutually entangled. ${ }^{2}$

Context is not only descriptive; it is constitutive, as it was molded by the same forces which are put under an analytical lens (Dilley 2002, 439). To contextualize is to connect various points, relations, influences, not prioritizing any of them and having in mind the quality of the "whole". As Dilley points out, the "context" is made of different sets of social relationships connecting the institution or phenomena to the wider society or other institutions. Contextualization can be described in the same way as interpretation - as an "act of creating connections" (Dilley 2002, 440). Nevertheless, it has to be noticed that contexts connect and disconnect at the same time: "contexts are sets of connections construed as relevant to someone, to something or to a particular problem" (Dilley 2002, 440). It is important to emphasize the dynamism of the concept of context in anthropology: it is not a "background" for the better understanding of a phenomena, it is seen as a "condition which gives rise to cultural meaning" (Dilley 2002, 448). Therefore contexts are not "self-evident aspects of reality that are pre-given, or to be taken-for-granted, in the sense of being understood as existing prior to analysis. They are part of the analysis and interpretation itself" (Dilley 2002, 449).

In this paper I will briefly outline the context in which television culture in socialist Yugoslavia gained momentum in the late sixties and early seventies, pinpointing two episodes: the penetration of TV into small places and villages and the socio-cultural influence and ramifications of the broadcast of "Peyton Place". These examples serve to illuminate the remarkable socio-cultural process of privatization, which transformed both the social life and practices of TV viewing. The main body of empirical material used in this paper consists of articles, commentaries, and letters from the viewers and illustrations from one of the most influential TV magazines - TV Review (published in Serbia but read throughout socialist

\footnotetext{
${ }^{2}$ Material for this paper came about as part of a wider research on the role of TV in the representation and lived experiences of modernity in Yugoslav late socialism. Its fragmented character is partly due to the scope of the work to which it initially belonged, but it is also a matter of the theoretical and methodological choice I made to approach TV ethnographically, with particular attention to details, through Gertzian "thick description". Thorough contextualization is a key tool in this approach, and it offers a rich reservoir of the interconnectedness of different areas, actors, events, activities in society. On the other hand, it can sometimes fall short in giving answers to the questions that aim for precision, clarity and representativeness.
} 
Yugoslavia). The way this material was approached and used for "making connections" (that is for contextualizing/interpreting) follows the logic of ethnographic research - it was used as parts of a body of various texts and practices "which the anthropologist strains to read over the shoulder of others" (Geertz 1973, 452, in: Dilley 2002, 449).

The paper consists of three sections. In the first section I will present a brief overview of the institutionalization of TV broadcasting in the country, outlining the intentions of its creators and political sponsors to profile socialist television primarily as a "creator of social(ist) values" and "proper citizenship". In the second part I illuminate a slow but steady process of transitioning of TV - in terms of television ownership and TV watching practices - from an exclusive to a widespread medium, and from a collective to an individual arena of its consumption. Both processes contributed to the rise in TV's influence on society, often in unexpected ways which were also less controllable. Finally, in the last section of the paper I present an example of failed attempts in the early 1970s made by political authorities to tame these influences - and thus try to control the "private pleasures" (interpreted as a potential threat to socialist moral and political projects) which TV watching enabled, through ideological criticism of popular TV, exemplified in the American TV series "Peyton Place".

\section{NEW MEDIA FOR A NEW SOCIETY - INSTITUTIONALIZATION OF TELEVISION IN SOCIALIST YUGOSLAVIA}

Belgrade Television officially started broadcasting on August 23, 1958, when its experimental program launched at the Second Fair of Technologies. According to recollections of those who took part in this extraordinary event, it provoked great interest and excitement, both of the creators of the "new television" and of its (future) audience. The stakes were particularly high for the people most involved in agitation for the introduction of this novel medium - engineers and technicians from Radio Belgrade, and also the politicians, members of Communist Party, who endorsed their initiative. It was clear that their professional and political futures respectively would depend on the estimated success of the first broadcast, for television was an investment too expensive to fail. Furthermore, TV was taken seriously in socialist Yugoslavia because it was expected to become a powerful tool in the development of socialist culture, bringing up of "proper socialist citizens" and functioning as a token of aspiring modernity of the new Yugoslav society (in more detail on television as an important agent in political socialization and development of "proper socialist citizens", see Reifova 2002; Bren 2011; Havens, Imre and Lustyk 2013; Gumbert 2014; Imre 2016; Mihelj and Huxtable 2018).

In order to reach a mass audience, technicians and engineers installed TV sets at 80 points in Belgrade's city centre, including shop windows in the main streets and squares, where people could gather to watch the broadcast. ${ }^{3}$ Since Yugoslav industry was still unable to provide the mass production of TV sets, on this occasion predominantly foreign products were used, provided by renowned TV producers as part of their marketing efforts (Žižić 1986, 110). TV sets were installed into homes of selected state and party dignitaries: Edward Kernel, the main ideologue of the Party at the time, Aleksandra Ranković, the Minister of Internal Affairs and a close associate of President Tito and Petar Stambolić, a powerful communist dignitary both in national political bodies (in

${ }^{3}$ On Terazije Square - 5, in Knez Mihajlova St. - 3, on Kalemegdan - 1, in Marshall Tito St. - 4, on Marx and Engels Square -5, in Revolution Boullevard - 6, in several uptown settlements about 60 more TV sets (Žižić 1986, 111). 
Serbia) and on the federal, Yugoslav level. On-site technicians were designated to help during the broadcast in public spaces - to solve possible technical problems but also to explain the new technology to the audience and to answer their questions, while in the homes of the dignitaries one member of the household was previously instructed how to handle the TV set (ibid). The program officially started at 8:55 p.m. with an image of "The Victor", a historical landmark in the capital city and a song "The Anthem for Belgrade" (written by renowned composer Mihovil Logar), that would become the insignia of Belgrade Television and continue to live as a memory to TV broadcasting for several generations in the decades to come. For years the program had started with this opening, whose portrayal and lyrics resembled the free and fighting spirit of the time and the Yugoslav national character of the new television.

From the very beginning of the TV broadcast it was evident how this novel media would work as the means of "re-enchantment" in the technologically-driven modern world. In Yugoslavia, "TV magic" already cast its spell over the mesmerized audience during the socalled "Fair broadcast" in the summer of 1958. Dazzled by the wonders of new technology, people thought about TV in terms of "sensation" and "attraction", and gathered in the streets of Belgrade to watch how this "wonder" worked. "Politika", one of the oldest and most influential daily newspapers in Yugoslavia wrote: "In the evening, the streets of Belgrade do not have their usual look with hundreds of casual strollers. In these late summer days, it seems that there is much more Belgraders than the statisticians have recorded. On dozens of the most frequent spots in the city center large groups are gathering, jostling and stretching on their tiptoes, trying to get a better view of 'something'. That 'something' are in fact TV screens through which Belgrade Radio-Television has, for five days already, been making its first, though firm steps" (Žižić 1986, 117). After the "Fair broadcast" ended, "Politika" summarized the endeavor: "In the course of twelve days (few hours a day), we have been watching, on the streets and in kafanas, the first experimental program of the Belgrade Television. Its appealing power showed itself from the start, for large groups could not take their eyes off the TV screens. Clear picture and the undisturbed flow of the program were a pleasant surprise for the watching audience". ${ }^{4}$ It was also recorded that a huge TV audience of an estimated 100.000 football fans had watched the nightly football match between "Partizan" and "Honved" - the first sport event ever that could have been seen outside the stadium, due to television (Žižić 1986, 117).

Shortly after, domestic industrial production of TV sets was initiated in different factories throughout Yugoslavia: RIZ (Zagreb, Croatia), EI Niš (Serbia), "Rudi Čajavec" (Banja Luka, Bosnia and Herzegovina), but the pace of production was slow until the end of the fifties, only to rocket during the sixties and thus enable a television culture to grow and flourish during that decade. Quite a modest quantity of TV sets, compared to the needs of an interested audience, resulted in collective viewing practices which are mentioned as part of viewing history in existing writing on socialist TV (see, e.g. Imre 2016, Mihelj and Huxtable 2018, for Yugoslav context Dragičević-Šešić 2007, Erdei 2020). To this I will add one vivid account, a short memoir on the arrival of the first TV set into a household in a Serbian provincial town, written by Predrag V. Kovačević, then a young boy. After a cousin brought his family a TV set from Belgrade, and after they managed, with the help of another cousin, to obtain an antenna to fine tune the picture, Predrag remembers how the whole neighborhood gathered in their living room during the

\footnotetext{
${ }^{4}$ I. Bešević, "Prvi program beogradske televizije" ("Belgrade Television 1"), "Politika" 5. September 1958. According to: Žižić 1986, 117.
} 
times of the TV broadcast. "Evening gatherings became traditional in our home in the next few weeks. As the time for Central News approached, the neighbors would start arriving/coming, each carrying their chair, and some of them also with something to eat and drink. While watching TV, we used to drink soda, homemade pies or pancakes, freshly made for the event, so for us kids most of the time it was about socializing, eating delicious food and having fun regardless of the programs that were running on TV" (Kovačević 2015).

Their neighbors aside, people also used to pay such visits to their relatives and friends, or they went to different public places in cities and villages - such as community centers, cultural centers, or even local shops if those were the only available gathering places in remote villages - to follow the News and popular TV shows and series (Dragićević-Šešić 2007, 74041). Sometimes it was for free, but on occasions a (modest) price was put on the watching experience. As Predrag V. Kovačević remembers, in Titovo Užice, a town in Western Serbia, "in the 1960s the local community office bought a TV set for public viewing. Watching TV News was for free, but for watching the TV series which ran after the News you had to pay few dinars (...)". Kovačević also testifies about the rising popularity of various TV series, mostly imported from the West (particularly from America), the broadcasts of which literally emptied the streets and kafanas in his town (and in many others for that matter). To watch popular TV series "The Long, Hot Summer" which ran in 1967, you had to pay 20 dinars (which, as he compared, was equivalent to the price of two scoops of ice-cream at Miki's or one baklava (oriental sweet, I. E.) - but who cared about baklava when you could watch Ben Quick and Clara!) (Kovačević 2015). Those collective viewing practices during the sixties, argues Rodoljub Žižić, could have influenced the character of social interactions between people as well - some of them knew each other and some of them were unfamiliar with the group and were led to join only by their desire to watch TV. Therefore, in some cases, the activity of "watching TV" dominated behavior during the gathering and foreshadowed all other social activities that used to happen before - smooth socializing, small talk, gossiping, joking. Instead, all the attention was directed to what was happening on the "small screen", and people were barely talking with each other. "Conversation between people was limited to the period before the program started. People usually came for the program, and left shortly after its end. As if they were in the cinema, when the broadcast was over, they would stand up and leave" (Žižić 1986, 119). Nevertheless, collective watching had produced a sense of togetherness, not only out of the physical closeness of the watching crowd, but also because it was characteristic of the era when Television Belgrade still broadcasted its programs on one channel only, which effectively produced a rather homogeneous audience and an interpretative community with a high level of sharing experiences, emotions, attitudes brought to them by TV.

However strange it might appear to today's TV viewer (and even stranger to the members of the internet generation), until the beginning of the 1970s all of those watching TV in Yugoslavia had watched the same programs, and discussed them the next morning, commenting on them, criticizing them, establishing, in the long run, strong connections with the new TV celebrities, actors, singers, program hosts etc., mimicking their way of talking, movements and even some of the catchphrases they used. It was common to retell and comment on the latest episode of the popular series, particularly domestic ones, whose plots, characters and situations were familiar to the viewers and easy to identify with. It was as if a secret code of understanding was established: if one cracked a joke in the manner of popular comedians like "Mija and Čkalja" (Miodrag Petrović Čkalja and Mija Aleksić, a well-liked Yugoslav comical tandem), everyone immediately understood not only what it was about, but were able to engage in the joke, 
mobilizing the shared cultural resources and the shared viewing experience. ${ }^{5}$ The same occurred after broadcasts of the then popular music festivals: the next day all would talk about the way the singers were dressed, commenting on their performances, and the most appealing or the winning songs would have been whistled by hundreds of thousands. ${ }^{6}$ Those were the beginnings of the power of television as a global (and globalizing) cultural force that would fully develop several decades on.

Collective viewing practices (in the company of family and neighbors) continued into the sixties, and in the villages for even longer, until eventually the number of TV sets did provide a transformation of TV viewing into private practice. Early on, this had also turned television sets - as scarce commodities - into objects of desire and ways of displaying social status. At the beginning of domestic production, it took 15 monthly paychecks to buy a TV set (Žižić 1986), which gradually changed during the sixties, coupled with the rising standard of life fostered by the turn in government orientation toward the "policy of standard" in 1955. As the production of TV sets grew, their price gradually fell and by the end of the 1960s they became widely available. "People have been buying TV sets as they used to buy peppers in autumn" (to prepare traditional preserves for winter, I.E.), noted down Novak Novak (the artistic name of Novak Novaković), one of the most famous TV writers, describing the enthusiasm that surrounded television during those times. ${ }^{7}$ Thus the number of TV subscribers in Serbia rose from 30.000 at the beginning of the 1960s to more than 300.000 at the end of the decade (Dragićević-Šešić 2007, 746), and the statistical data shows that throughout the 1970s the number of TV sets, along with washing machines, rose exponentially. In Croatia in 1978, 65 out of 100 households owned a black-and-white, and only 9 a color TV (Duda 2014, 149). While in the early 1960s a TV set was worth 7 monthly wages, at the end of the 1970s it was equal to a monthly wage (Duda 2015, 49).

It is evident that after two decades of existence television had grown to fulfill the expectations of its founders - it became a widespread, popular and influential new media, able to inform, educate and guide socialist citizens towards their social roles and responsibilities. On the other hand, it appeared that television was also there to entertain, to make people laugh, to enlighten and even sharpen a critical view on society (although state television remained under the strong hold of the ruling Party in Yugoslavia, as in other socialist countries, until the demise of socialism at the end of the eighties). Balancing and negotiating between these roles, positions, loyalties and responsibilities was for the most part the way TV operated during socialism.

\footnotetext{
${ }^{5}$ There are a lot of examples of strong identification with TV characters in the early days of television. This phenomenon could be explained by a certain naivete which existed toward the new media in the first years of broadcasting. Still, it was also related to the nature and quality of TV writing that was in tune with everyday life, able to capture the preoccupations and worries of the many. There is a story that wonderfully illustrates this: during the airing of the TV series "Wax Museum" (1962-1963), in an episode broadcasted after the New Year Celebration, one of the main characters, Mita, played by Miodrag Petrović Čkalja, groans about having a headache after drinking too much. At the end of the episode, Čkalja cries: "Oh, my, my head is bursting, if only I could get some brine (rasol)". In a few days, "several thousand liters of brine arrived to the TV studio, in varying containers: bottles, cans, bins, together with regards, greetings and good wishes for Mita's successful recovery" (Đukić 1987, 273).

${ }^{6}$ Miroslava Malešević, personal correspondence.

${ }^{7}$ Manuscript of the Memoirs of Novak Novak, IAB, LFNN, K7/III-23 (23.1-23.2).
} 


\section{INDUSTRIALIZATION, URBANIZATION, MODERNIZATION AND THEIR "RURAL BACKYARD"}

The process of rapid industrialization in Yugoslavia was conceived after the Soviet model of social and economic development, and it brought about significant demographic changes and massive movement of the population from rural areas to urban centers. Marie-Janine Calic wrote that "between 1945 and 1953 1,5 million people left the countryside to settle permanently in the city. Additional 800.000 became temporary industrial workers or commuters" (Calić 2013, 229-30). In the 1950s and 1960s these numbers rose further - four million people left their villages from 1953 to 1970, half of them did it over the course of the 1960s. Belgrade, as the capital of Yugoslavia, lured most of them. From 1961 to 1971, as a result of intensive rural-urban migrations, about 18.000 inhabitants moved to Belgrade annually (Krstić 2018, 134). Not only did Yugoslavs from remote parts of the country recognize the rapid change of Belgrade, and its growing into dynamic modern European city, foreign visitors also left accounts of this impressive transformation. The "Washington Post" correspondent, a former native of Belgrade whose family left Yugoslavia shortly after World War II, wrote about his impressions when he came back to visit in the early seventies: "Belgrade was a brisk, frivolous, noisy city, a crowded and dynamic city compared to the one I remember from twenty years ago (...) As we rushed along the firm, straight arrow of the highway (...) the familiar Coca-Cola sign appeared at the edge of the cornfield, with a line in Cyrillic, osvežava najbolje (refreshes the best) under large Latin letters. Then came colourful, Western-style ads for Pan Am, Lufthansa, Volkswagen, Siemens, various hotels, washing machines, furniture, Fiat, banks, service establishments. It was as though Tito's ideology had been submerged in a flood of automobiles, washing machines, electrical gadgetry and minicomputers (...) And the people: well-dressed crowds in the street that might fit anywhere in Western Europe, or almost everywhere. Women wore chic clothes and make up. It seemed as though a Western type of consumption had brought Yugoslavia closer to Western Europe's style of social life" (Doder 1979, 5-6).

Although the main stage of modernization of the country was its capital city, followed by many towns now turned into industrial centers, its rural parts were also made into the "object" of modernist scrutiny, and were expected to change as well. Penetration of television into villages and into the countryside was considered as one of the measures of success of the modernization of the society, while simultaneously being the method by which this modernization was brought about. This is most vividly pictured in the popular TV magazines which started to flourish already in the mid-1960s: "Studio" in Zagreb, "TV Novosti" ("TV novelties") $)^{8}$ and "Radio TV revija" ("Radio TV review") in Belgrade. Along with consumption culture that started to establish itself from the mid1950s, these magazines gave a strong push to the development of TV culture in socialist Yugoslavia. In them, the interested reader could find the schedule of the TV program, articles about popular TV personalities, actors, directors etc. They could also reach out to the program creators with comments, suggestions, critiques, or just to describe the ways television has changed their everyday lives and ways of seeing the world. Thus letters sent by an audience from all of Yugoslavia - from big cities inasmuch as from small

\footnotetext{
${ }^{8}$ The first number of the magazine has been issued in December 24th 1964 by publishing company "Večernje novosti". "Večernje novosti" was known for publishing newspapers and magazines aimed to wide public, inclining toward short information, light entertainment and promotion of celebrity and TV culture.

${ }^{9}$ The first number was issued on March 3, 1967 by the publishing company "Politika", in cooperation with Belgrade Radio Television.
} 
villages - were published in "Radio TV review" under the rubric "Readers, spectators, listeners". Through them the audience, eager to get closer to "their" television, demonstrated the degree in which television was domesticated and had become inseparable from the fabric of their everyday lives. In one of these letters, Milivoje Radovanović from Belušić village, near Svetozarevo in Central Serbia, proudly claimed that in their small village with around 300 households there were 170 TV sets. As we learn from his story, the village won first prize in the contest "Village with most TV sets (compared to number of households)", created by the "Radio TV review" magazine. The prize came in the form of the possibility to host a live recording of the program "Merry village" ("Selo veselo") in the local venue of the so-called people's university (narodni univerzitet). ${ }^{10}$ Milivoje added that Belušićans were also avid readers of "Radio TV review" - the 100 copies of the magazine which arrived to their village were snapped up immediately. "It just so happens", Milivoje wrote, "that some copies were resold for the price of 5 dinars (original price was 1 dinar - I. E.) in a few days, that is after some 'businessman' read it through"; he finished the letter with an appeal to the editors to send more copies to the village. ${ }^{11}$ We could see from Milivoje's letter that "televisionization" of the rural areas was an organized and orchestrated attempt by the state, industry, media and showbiz actors, all of them navigating a particular agenda on a common modernization path. Enabling every corner of the country to have a TV set, through which the creation of an "imagined community" of socialist citizenship would be possible, the State had in mind the enlargement of the audience, understood primarily as political and social collectivity. Soon enough it became clear that messages and imagery born out of attempts to liberalize the economy (particularly after the Economic Reform in 1965), would find a way to the Yugoslav spectatorship, through advertising and other visualizations that mediated consumer culture. Sometimes TV viewers found this move towards commercialization puzzling: on the one hand they embraced foreign entertaining programs, such as TV series, and on the other hand protested against commercial breaks which interrupted the broadcast (e.g. series of letters in "RTV review" complaining about commercials interrupting the popular series "Peyton Place"12 in 1970/71), obviously not realizing that both were part of the same transformation toward more "popular" media (for this transformation see more in: Bren 2011, Havens, Imre and Lustyk 2013, Daković, Milovanović 2015, 2016, Imre 2016, Mihelj and Huxtable 2018).

That rural population represented a particular target for modernization through the diffusion of television, which was noticeable from the comical cartoon that regularly appeared in "Radio TV review". The main character in the cartoon is villager Radojica, and the main theme relates to various encounters villagers have with television and the "outer world" brought to their homes by TV. Radojica stands as a stereotypical representation of all "rural folk", although he is presented in the "Serbian rendition": his name clearly refers to Serbian peasant society ancestry, he is dressed in Serbian traditional attire, wearing a šajkača cap and opanci (leather shoes), riding a tractor and, in general, being on the receiving end of

\footnotetext{
${ }^{10}$ This represents evidence that the penetration of television (as technology, media and part of new culture of domesticity) into the rural areas was part of an organized effort, aimed to include even the remotest parts of the country into the "immagined community" of the Yugoslavs, via shared televisual content.

11 "Rekorderi" ("Recorders"). Radio TV revija 206, 5. 2. 1971, p. 49.

12 "Peyton Place" was an extremely popular American TV series, which originally aired from 1964 to 1969 on $\mathrm{ABC}$. It is set in a small town and covers a complex (sometimes complicated, sometimes shady) sets of relations between inhabitants of a small American town. Today it is considered to be "a grandmother" of today's TV soap-operas.
} 
modernization. However, his shrewdness is celebrated in the cartoon. Radojica's lively world shows how rural regions went through modernization, the uneven workings of the modernization process, and also the place TV had in it. Thus in the three-part cartoon, published in the first issue of "Radio TV review" in 1967, we could see Radojica reading the magazine and getting the idea to purchase a TV set (first frame), going to the store and buying it (second frame) and finally looking at the black screen under the light of a petroleum lamp, when we realize that Radojica's village still lacks electricity (Fig. 1). ${ }^{13}$
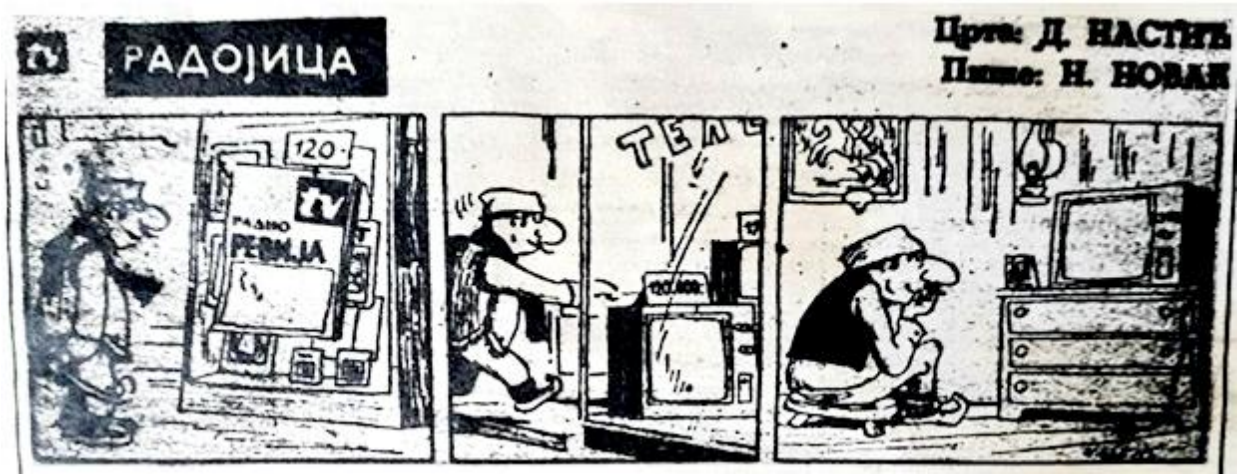

Fig. 1

Later on, in the early 1970s, Radojica becomes confused after watching "Peyton Place", because the representation of traditional romantic love between the protagonists (and a representation of fragile, beautiful women immersed in love, as part of it), was immediately followed by (for him) an opposing representation of women advertising instant soup, which left him wondering what ideal of womanhood TV offered. "I do not understand", says he, "a boy and a girl fall for each other... and the boy had just kissed the girl when another girl showed up to demonstrate... how to cook instant soup!?” (Fig. 2).

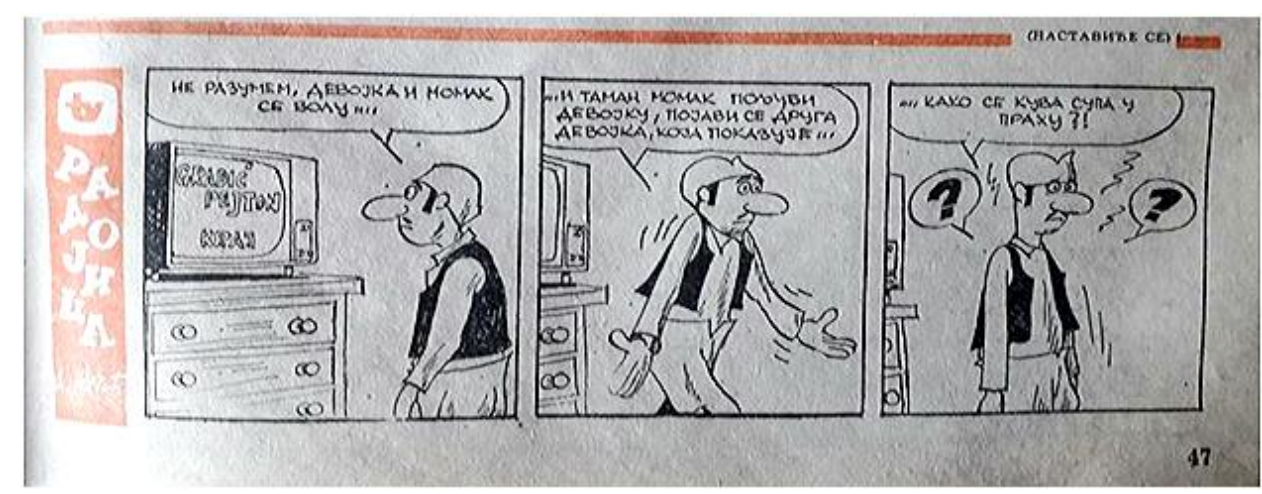

Fig. 2

${ }^{13}$ RTV revija, no. 200, 25. 12. 1970. 
As we saw in the case of Radojica who felt the need to buy a TV even before electricity came to his village, in some cases TV culture preceded the actual experience of watching TV in one's home. The magazine "Radio TV review" published plenty of stories of families who did not have a TV set, but nevertheless participated in TV culture, due to possibilities of collective watching and/or reading TV magazines. Marica Živković from Garčin near Slavonski Brod (Croatia) wrote: "Thanks to 'Review' I think I can count myself among well the informed persons about cinema world, pop and folk singers and international singing stars. To understand what the "Review" means to me, you have to know that I live in the countryside and that transistor-radio and your magazine enrich my life - and all that for only 1 dinar a week". ${ }^{14}$ Pavle Klačik from Stara Pazova in Vojvodina confirmed that he had been reading the magazine for two years before finally buying a TV set. Branka M. Knežević from Banatski Dvor in southern part of Vojvodina tells that, in her household, the "Review" replaced the TV set that is missing, and explains why: "My parents cannot acquire a TV set because they have to provide for the schooling of three children; still, we are grateful to them for supplying us with the 'Review' regularly. Reading it makes all of us very glad." 15

\section{4. "PEYTONIZATION" AND BEYOND: ONE FAILED ATTEMPT OF IDEOLOGICAL TAMING}

Various sources show that TV was the primary source of entertainment for Yugoslavs throughout the sixties and seventies, and indicate the pace of privatization of television watching. Many of the texts in the newspapers as well as memoirs mention "empty streets and kafanas" during broadcasts of the most popular programs (especially TV series, but also quizzes and sport matches). ${ }^{16}$ It reveals the enormous capacity in which TV contributed to the modernization of society. "Many people who maybe never, or seldom visited the theatre, now have had a dramatic performance brought to their homes at least once a week. Sitting in their living rooms viewers could get to know politicians, statesmen, various artists, sportsmen and women, Yugoslav and foreign. So many actors were brought out of theater halls, and given opportunity to perform in front of audience of millions, thus turning them into celebrities walking on "TV's (red) carpet"" (Žižić 1986, 120). Before "Peyton Place", the TV series "The Long, Hot Summer"17 was also

\footnotetext{
14 "'Revija' umesto TV" ("Review instead of TV"), "Radio TV revija", No. 199, 18.12.1970, pp. 49.

15 "'Revija' umesto TV" ("Review instead of TV"), "Radio TV revija", br. 201, 1.1.1971, str. 19.

${ }^{16}$ An article titled "Empty" printed in "RTV review" in early 1970s speaks of empty streets during the airing of the newest TV quiz program. A reader complains that last Friday he was sitting alone in a kafana, "in the company of a waiter, one sleepy pensioner and the lottery seller who was the only passer-by. 'What is happening'? Is TV ruining the local businesses again'”, asks him, in disbelief that the TV show "left kafanas, movie theaters, concert halls and dramatic theatres empty, as used to be when Lola Đukić's TV series were aired" ("Prazno", "Radio TV revija", no. 206, 5.2.1971, p. 7). Lola Đukić himself remembered that his TV series "Service station" (1959) was so popular, emptying the streets, that "one Congress held in Sarajevo has rescheduled the session because of it, and people from catering business have offered me a decent amount of money to stop making these TV shows which empty kafanas... (Đukić 1987, 269).

17 'The Long, Hot Summer" is an American drama series broadcasted on ABC TV for one season from 19651966. It was about class marked relations between members of a wealthy family and economically less well off, including a drifter whose arrival stirred the wealthy family, in a town situated in Deep South, Mississipi. Attention of the audience and its identification with the characters was caught mostly through the love story between Clara and Ben Quick.
} 
the source of "cultural radiation". Its main characters - Clara and Ben Quick gained huge popularity as did the song with the same name from the series which aired for a long time on Radio Belgrade. ${ }^{18}$ It was not before long when "The Long, Hot Summer" song got its "folk" reading which circulated through popular places of gathering and strolling (korzo): "My darling is sweeter than Ben Quick, my Mary is cuter that Clara", though in original it was a folk-tuned rhyme: "Moj je dika slađi od Ben Kvika, moja Mara ljepša je neg' Klara" (Kovačević 2015). However it was "Peyton Place" that broke the record and became a truly social phenomenon. Calculations of its ratings showed that there were 6,6 viewers per 1 TV set, sales of TV sets and antennas rose as people were trying to "catch" the program of TV Zagreb because they aired the new episodes earlier than TV Belgrade. After its airing at Sunday noon caused dismay at family lunches, the timing was changed, which emptied streets in the afternoon; on Mondays everyone would comment on it (Pašić 1987). When in June 1972 the leading actors visited Yugoslavia, it provoked a frenzy similar to the visit of Roy Thinnes (the actor who played Ben Quick) before. As was noted in the newspapers, "they were greeted everywhere with bread and salt (traditional welcome ritual, I.E.), in front of the tobacco factory in Vranje a folk dance performance was organized and local directors were offering them roles in their movies (ibid). The impact television and TV series had on everyday lives of the viewers could be observed and traced through a wide spectrum of cultural practices - from posters hanging in corridors and kitchens (as many people remember), to hairstyles modelled after the characters in the TV series, to an undocumented story about a hotel on Dalmatian coast in Croatia that was named after the protagonist of the TV series "Peyton Place". The hotel was opened in the early 1970s, representing the signature design of the leading modernist hospitality architect in Croatia Zdravko Begovac. According to the story, Barbara Perkins, the actress after whom the Hotel "Barbara" was named, came to Yugoslavia to attend the opening ceremony and to be the hotel's "godmother"”' (Kovačević 2015).

As an extremely popular TV series, "Peyton Place" also represented a landmark in TV advertising. Announcing the beginning of the airing, journalists warned the audience that "there would be interruptions", elaborating that there would be six interruptions, each 30 seconds long, and explaining the reason behind it. Namely, 12 Yugoslav companies have "paid" to enable the airing of the TV series, therefore they would use the TV time to advertise their products. The response of the audience, which also shows how deeply television has penetrated into everyday life of its viewers and how seriously they have been taking it, could be grasped by perusing their letters to "Radio TV review". The attentiveness that is evident in their writings is striking, as is the open and frank way they were relating with TV, with the intention to participate in the development of television which was obviously seen as contributing to the common good. Some letters object to the evidently novel introduction of commercial breaks into the program. Mirko Topić from the town of Šabac in Western Serbia complained that the interruption of TV series with blocks of commercials is "testing the nerves of the viewers" and suggested presenting all the commercials at the beginning or at the end of the episode instead. Evica Crljen from the village Golubinci in Vojvodina disagreed with the timing of the airing - because of the everyday village routine, she goes to sleep rather early. She brought forward the fact that people who live in villages usually do not go anywhere at Sunday afternoons and suggested that Sunday 6 P.M. would be an

\footnotetext{
${ }^{18}$ At that time Radio Belgrade was the only (local) radio station in socialist Serbia that could be officially listened to (apart from Radio Luxembourg which was listened to secretly).
} 
ideal timing for airing of "Peyton Place". She also reminded the editors that the TV series "The Forsyth Saga" and "The Long, Hot Summer"19 were aired exactly at that time so "all the viewers had an opportunity to watch them". ${ }^{20}$

Young Milena Petkov, introducing herself as a "pupil from Novi Kostolac" (in Eastern Serbia) agreed with Evica on the inappropriateness of the schedule, though for the younger viewers because they also, for other reasons, had to be in bad earlier and therefore "were compelled to miss one of the most popular programs". She also thought that the TV series should be aired on Sunday afternoons. ${ }^{21}$ Answering to the appeals, the editors revealed a long list of those expressing the same wishes among which were also "workers of the second shift in Combine Borovo" (Croatia). Young housewives, however, found this timing's silver lining: Mila Zdravković from Belgrade realized that it befits her "as a working women and homemaker". During the breaks, as she said, she could prepare a cup of coffee or check on the meal she was preparing for tomorrow's lunch: "Many are not pleased having to stay awake until late to watch 'Peyton Place'. Yet my friends and I were awake anyway because it was only then that we managed to finish the housework". A variety of concerns include those who understood the importance of advertising as a new force of economy and commercials as a way for producers to establish better communicate with their customers.

Finally, Faruk Musemić from Janje in Bosnia and Herzegovina showed great understanding of all the issues that were previously taken up by other viewers and posed a rather unusual complaint: he protested because the credit list at the end of each episode of "Peyton Place" was cut off, so he was not able to record the names of those involved, and that was his hobby for years. "I have been recording names of actors, directors and other stuff in TV series. So far I collected 125 names from the TV series "Untouchables" only. Why are we, whose hobby is name collecting, prevented from practicing it? So far I have 48.755 names written down in my notebook, and I want to continue". ${ }^{22}$

Readers' letters give us a glimpse into one more phenomenon connected with fermenting TV culture: strengthening the social base of popular culture through the creation of a devoted fan base, which was connected with the creation of sub-cultural identities founded on the affinity toward a particular type or genre of music (e.g. traditional, new folk, popular, jazz etc.), or to particular performers (e.g. famous singers Đorđe Marjanović and Miki Jevremovic had "tribes" of ardent followers who referred to themselves as "đokisti" and "mikisti"). Sometimes it seems that these socio-cultural divisions echo tensions between audiences from different parts of Yugoslavia, which does not come as surprise knowing that the process of "protonationalization" of the former integral Yugoslav mediascape had been evolving during the seventies (see: Mihelj 2014, 2018). One occasion during which these tensions could be sensed in the readers' correspondence was a dispute between the fans of Gabi Novak, a singer from Zagreb (Croatia) and aficionados of Đorđe Marjanović, a singer from Belgrade (Serbia), about the statement that Gabi allegedly made, questioning the

\footnotetext{
19 "The Long, Hot Summer" ("Dugo toplo leto") was one of many American TV series broadcasted in Yugoslavia during the sixties, along with "Dr Kildear", "Bonanza", "Peyton Place", "The Forsyth Saga" etc. Influence of the American culture and way of life was undoubtedly achieved through TV and movies. On that process in Yugoslavia see: Vučetić 2012.

20 "Peyton Place" ("Gradić Pejton") was aired in different times. This refers to the timing when its airing was closer to the end of the program, just before the Nightly News.

21 "Why not on Sundays" ("Zašto ne nedeljom"), "Radio TV revija", no. 208, 19.2.1971, p. 49

22 "Peyton, blitz, or...?” (“'Pejton', blic ili...?”), "Radio TV revija”, no. 205, 29.1.1971, p. 49.
} 
popularity of Đorđe Marjanović in the SSSR, where many of Yugoslav singers, including Gabi and Đorđe, enjoyed great success. Ahmet Ahić, a soldier who was doing his military service in Leskovac in Southern Serbia, quite obviously a big fan of Gabi Novak and Arsen Dedić (her companion in music and life), reacted to the dispute with a letter titled "Easy, Đokisti!", and wrote: "Calm down, Đokisti! Do not make a fuss for no reason. If you don't agree with what is written about your favorite artist, there are also other people who will argue against incorrect treatment of Gabi and Arsen. I'm ready to fight - in music and words."23

\section{CONCLUDING REMARKS}

From everything mentioned above the intention and enthusiasm of the audience to take an active part in the development of "their" television and its programs is clearly visible. In that way the audience showed a will to play a part in the creation of TV culture instead of being its passive recipient, expressing not only their civic responsibility but also their private pleasures and fidelities. Innumerable TV stars - news anchors, actors, singers, TV presenters - owe their celebrity status to the persistent interest of ordinary people who followed them all along. By the early 1970s television has already achieved the status of omnipresent media. TV sets became the center of the household, a gathering point for the family members and friends and a "window into the world". Through it many internationally important events, such as the historic Apollo 11 Moon Landing in 1969, were brought into homes of ordinary people, making them a part of the global spectatorship.

Attachment to Western TV programs felt by Yugoslavian audience was attested by the popularity of "Peyton Place", through which, as contemporaries have noted, "Western culture sneaked into our homes and minds. As children we could find the love story between Rodney and Alison from Peyton Place dull, but all the other things that we noticed during the airing (the surroundings, houses, clothing, the way they act, speak and relate to each other) left a lasting mark in our lives by establishing standards for our aspirations and conceptions of success in life for long - it was an ideal of American middle class way of life" (Kovačević 2015). Although at the time of the airing of "Peyton Place" consumer culture in Yugoslavia was well developed and the standard of life already heading toward its peak in the late seventies (acc. to Duda, the standard of life was the highest in 1979; Duda 2015, 156-57), alerts and warnings from certain echelons of the Party and vigilant public to the dangers of "consumerism" and "bourgeois mentality" never ceased to exist. Modes of consumption which were seen as overstepping the boundaries of the "modest", "socialist" and "cultured" were perceived to be "mindless", resembling the way of life in (capitalist) West too much and therefore declared to represent a "socially detrimental phenomenon". "Peyton Place" was turned into a metaphor - "peytonization" - and used as a qualification and ideological accusation in Party disputes in Serbia and in Croatia between their "hardliners" and "liberal" wings in the early seventies (cf. Pašić 1987). Afterwards, the notion of "peytonization" was employed in Party debates and the subsequent public discussions, to express concerns about the weakening of the Party's "ideological forte". Spreading moral panic by stating that "'peytonization' overtook the masses" and pointing to other sources of "Western" influences on the young, such as rock and pop music, the authorities eventually stopped the broadcast of this TV series in Yugoslavia (ibid). Still, TV culture had already firmly established its roots,

\footnotetext{
23 “Calm down, Đokisti” (“Đokisti, lakše”), “Radio TV revija”, no. 210, 5.3.1971, p. 48.
} 
and the cultural influences steaming from the West had been mainstreamed so far and integrated into the everyday lives of Yugoslavs in many areas - from pop culture, to appearances, to home decoration, family relations to the lifestyles and leisure activities. Having been able to establish itself even before TV sets became widespread in Yugoslav households, TV culture would blossom during the seventies, when home-grown productions of TV series flourished, leading to the "golden age" of TV Belgrade.

\section{REFERENCES}

Abu Lughod, Lilla. "The Interpretation of Culture(s) after Television". Representations 59 (1997), Special Issue: The Fate of "Culture": Geertz and Beyond: 109-134.

Bren, Paulina. The Greengrocer and his TV: The Culture of Communism after the 1968 Prague Spring. Cornell University Press, 2011.

Čalić, Žan Mari. Istorija Jugoslavije u 20. veku. Beograd: Clio, 2013.

Daković, Nevena i Aleksandra Milovanović. "Socijalistički family sitcom: Pozorište u kući”. Zbornik radova FDU 27 (2015): 183-203.

Dakovic, Nevena i Aleksandra Milovanovic. "The Socialist Family Sitcom: Theatre at Home (Socialist Federal Republic of Yugoslavia 1972 - Republic of Serbia 2007)". In Television Beyond and Across the Iron Curtain, edited by Kirsten Bönker, Julia Obertreis and Sven Grampp, 124-147. Cambridge Scholars Publishing, 2016.

Dilley R. M. "The Problem of Context in Social and Cultural Anthropology". Language and Communication 22, 4 (2002): 437-456

Doder, Duško. The Yugoslavs. New York: Random House, 1979.

Dragićević-Šešić, Milena. "Privatni život u vremenu televizije". U Privatni život kod Srba u dvadesetom veku, priredio Milan Ristović, 733-767. Beograd: Clio, 2007.

Duda, Igor. Pronađeno blagostanje: Svakodnevni život i potrošačka kultura u Hrvatskoj 1970-ih i 1980-ih. Zagreb: Srednja Europa, 2010.

Duda, Igor. "Uređenje stana". U Nikad im bolje nije bilo? Modernizacija svakodnevnog života u socijalističkoj Jugoslaviji, 48-49. Beograd: MIJ, 2015.

Đukić, Radivoje Lola. Sklerotični memoari. Beograd: Novo delo, 1987.

Erdei, Ildiko. "Novi život na 'malom ekranu' i oko njega: počeci televizije u socijalističkoj Jugoslaviji (19551970)". Etnoantropološki problemi 10, 2 (2015): 405-426.

Erdei, Ildiko. "Fragmenti jugoslovenske socijalističke modernosti 1970-ih u TV seriji 'Pozorište u kući'". Etnoantropološki problemi 12, 2 (2017): 537-563.

Erdei, Ildiko. Moderni život u udarnom terminu: televizija, humor i politika u socijalističkoj Jugoslaviji. Beograd: Evoluta, 2020 (fothcoming).

Geertz, Clifford. Interpretation of Cultures (Selected Essays). New York: Basic Books, 1973

Gumbert L. H. Envisioning Socialism. Television and the Cold War in the German Democratic Republic. University of Michigan Press, 2014.

Havens, Timothy, Aniko Imre and Katalin Lustyik, eds. Popular TV in Eastern Europe During and Since Socialism. Routledge, 2013.

Imre, Anikó. "Adventures in Early Socialist Television Edutainment". In Popular Television in Eastern Europe During and Since Socialism, edited by Imre, Anikó. Timothy Havens and Kati Lustyk, 30-46. London: Routledge, 2013

Imre, Anikó. TV Socialism. Duke University Press, 2016.

Malešević, Miroslava. "Iskušenja socijalističkog raja - refleksije konzumerističkog društva u jugoslovenskom filmu 1960ih". Glasnik Etnografskog instituta SANU 60, 2 (2012): 107-123.

Mickiewitcz, Ellen. Split Signals: Television and Politics in the Soviet Union. Oxford University Press, 1988.

Mihelj, Sabina. "Television Entertainment in Socialist Eastern Europe: Between Cold War Politics and Global Developments". In Popular Television in Eastern Europe During and Since Socialism, edited by Anikó Imre, Timothy Havens and Kati Lustyk, 13-29. London: Routledge, 2013.

Mihelj, Sabina. "The Politics of Privatization: Television Entertainment and the Yugoslav Sixties". In The Socialist Sixties: Crossing Borders in the Second World, edited by Anne Gorsuch and Diane Koenker, 25167. Indiana University Press, 2013a.

Mihelj, Sabina. "Understanding Socialist Television: Concepts, Objects, Methods". VIEW - Journal of European Television History and Culture 3, 5 (2014): 7-16. 
Mihelj, Sabina, Simon Huxtable. From Media Systems to Media Cultures. Understanding Socialist Television. Cambridge University Press, 2018.

Miller, Daniel. Acknowledging Consumption, a Review of New Studies, ed. London and New York: Routledge, 1997. Reifová, Irena. "Kryty moci a úkryty před mocí: Normalizační a postkomunistický televizní seriál" [Shelters of power and hiding from power: TV series during the "Normalization" period and in post-communist times]. In Konsolidace vládnutí a podnikáni v České republice a v Evropské uni (Př́spěvky z konference konané ve dnech 31. 10 - 2. 11. 2002). II, Sociologie, prognostika a správa médií, edited by Jakub Končelík, Barbara Köpplová, Irena Prázová. Prague, 2002.

Simeunović-Bajić, Nataša 2016. Domaće igrane TV serije u jugoslovenskoj i postjugoslovenskoj popularnoj kulturi (Doktorska disertacija u rukopisu). Dostupno na: http://nardus.mpn.gov.rs/bitstream/handle/123456789/5027/ Disertacija639.pdf?sequence=1\&isAllowed=y.

Simeunović-Bajić, Nataša. "Posleratni bildungsroman jedne generacije kao vrhunsko delo jugoslovenske popularne televizijske estetike - TV serija 'Grlom u jagode'". EAP 13, 1 (2018): 93-109.

Vučetić, Radina. Koka-kola socijalizam. Beograd: Službeni glasnik, 2012.

Žižić, Rodoljub. Kroz ekran svet. Biblioteka prilozi za istoriju TVB. Beograd: Televizija Beograd, 1986.

\section{SOURCES}

Kovačević V. Predrag. Esej o početku televizije. 17 August 2015 at 03:59Public. Facebook (2015).

Novak, Novak. "Kako sam se upregao u serijska kola. Memoari TV pisca Novaka Novaka", "Danas", 5-19. novembar. Arhiv grada Beograda. LFNN, K7/III-24.2. (1998).

Pašić, Zorica. "Prababa svih sapunica", TV Novosti. Jugopapir. Fenomen popularnosti TV serije "Gradić Pejton": A onda su američki glumci stigli i u Jugoslaviju... Available at: http://www.yugopapir.com/ 2014/10/fenomen-popularnosti-tv-serije-gradic.html. (1987).

"RTV Review" Magazine 1969-1972.

\section{JAVNE VREDNOSTI I TAJNA ZADOVOLJSTVA: RAĐANJE TV KULTURE U SOCIJALISTIČKOJ JUGOSLAVIJI}

Televizija je tehnologija koja je promenila 20. vek, a takođe je bila i velika društvena i kulturna sila modernizacije nakon Drugog svetskog rata, sa obe strane Gvozdene zavese. U socijalističkim zemljama, televizija je bila blisko povezana sa ideologijom orijentisanom na budućnost, u cilju obezbeđenja demokratizacija znanja, promocije društvenih vrednosti i razvoja građana odanih socijalizmu. Početak tv programa u socijalistickkoj Jugoslaviji 1958. otvorio je vrata za postepeni razvoj tv kulture tokom šezdesetih $i$ sedamdesetih godina 20. veka, čiji se celokupan uticaj na subjektivizaciju i svakodnevni život publike ne može poreći. Cilj ovog rada bio je da se ukratko prikaže kontekst u kome se kultura televizije u socijalističkoj Jugoslaviji pojavila i razvila, u to u dva pravca: prodor televizije u manja mesta $i$ seoske zajednice tokom šezdesetih godina prošlog veka i društveno-kulturni uticaj i posledice emitovanja serije Gradić Pejton tokom ranih sedamdesetih.

Ključne reči: TV kultura, Televizija Beograd, navike publike, Gradić Pejton. 